\title{
Pharmaciana
}

Vol.11, No.3, Nov 2021, Page. 312-320

ISSN: 2088 4559; e-ISSN: 24770256

DOI: $10.12928 /$ pharmaciana.v11i3.20104

\section{The effect of Raphanus sativus and Pachyrhizus erosus juice combination on the ethanol-induced gastric of mice}

\author{
Reza Pertiwi ${ }^{* 1}$, Aanisah Hanuun ${ }^{1}$, Noval Kurnia Wati ${ }^{1}$, Petri Siti Khodijah ${ }^{1}$, \\ Dian Fita Lestari ${ }^{2}$, Dyah Fitriani ${ }^{3}$, Doni Notriawan ${ }^{3}$ \\ ${ }^{1}$ Department of Pharmacy, Faculty of Matemathics and Natural Science, Universitas Bengkulu \\ Jl. WR. Supratman, Kandang Limun, Kota Bengkulu \\ ${ }^{2}$ Department of Biology, Faculty of Matemathics and Natural Science, Universitas Bengkulu \\ Jl. WR. Supratman, Kandang Limun, Kota Bengkulu \\ ${ }^{3}$ Department of Chemistry, Faculty of Matemathics and Natural Science, Universitas Bengkulu \\ Jl. WR. Supratman, Kandang Limun, Kota Bengkulu
}

\begin{abstract}
Gastric ulcers can be caused by active inflammation due to impaired mucosal integrity, which causes local or widespread lesions. Gastric ulcers can occur due to the use of ethanol, which has a local effect on the gastric. Therefore, the continuous consumption of ethanol can damage gastric cells. Raphanus sativus and Pachyrhizus erosus contain flavonoids, which are well-known to reduce stomach acid as a curative agent. The objective of this study is to see the effect of Raphanus sativus and Pachyrhizus erosus juice as a preventive agent on alcohol-induced gastric ulcers in mice (Mus musculus). A combination of Raphanus sativus and Pachyrhizus erosus was given at a dose of 100,300 , and $600 \mathrm{mg} / \mathrm{kgBW}$. Specifically, Raphanus sativus was given at a dose of $300 \mathrm{mg} / \mathrm{kgBW}$, Pachyrhizus erosus at a dose of $300 \mathrm{mg} / \mathrm{kgBW}$, and positive control was included using sucralfate. The treatment was carried out for 12 days, and 1 hour after the last day of treatment, $20 \mathrm{ml} / \mathrm{kgBW}$ of ethanol induction was given 24 hours after the animals were dissected. The results showed that the index value of gastric ulcers in the normal group, negative control, and the combination of Raphanus sativus and Pachyrhizus erosus juice given orally at a dose of 100,300 , and $600 \mathrm{mg} / \mathrm{kgBW}$ (Raphanus sativus at a dose of $300 \mathrm{mg} / \mathrm{kgBW}$, Pachyrhizus erosus at a dose of $300 \mathrm{mg} / \mathrm{kgBW}$, and sucralfate as positive control) were $0 ; 4.00 ; 1.00 ; 1.33 ; 2.33 ; 2.67 ; 0$ and 2.00 . The results of the histopathological analysis also showed improvement in the gastric of mice fed with Pachyrhizus erosus juice. Therefore, it is inferred that treatment using Raphanus sativus and Pachyrhizus erosus juice can reduce the number of ulcers, increase ratio protection, and repair the cells in gastric histopathology. Additionally, giving a single dose of Pachyrhizus erosus juice results in a more significant gastric improvement.
\end{abstract}

Keywords: Raphanus sativus, Pachyrhizus erosus, gastric ulcer, gastroprotective

\author{
*Corresponding author: \\ Reza Pertiwi \\ Department of Pharmacy, Faculty of Matemathics and Natural Science, Universitas Bengkulu \\ J1. WR. Supratman, Kandang Limun, Kota Bengkulu \\ Email:rpertiwi@unib.ac.id
}




\section{INTRODUCTION}

Disease due to disorders in the upper gastrointestinal tract caused by the presence of pepsin and excessive acid secretion by the gastric mucosa is known as peptic ulcers. Gastric ulcers are characterized by impaired mucosal integrity that subsequently causes localized or widespread lesions as a result of active inflammation. The pathophysiology of gastric ulcers is caused by the imbalance of aggressive factors, such as Helicobacter pylori, pepsin, hydrochloric acid, and non-steroidal antiinflammatory drugs, as well as the local mucosal defensive factors, blood flow, prostaglandins, and mucus (Dharmani et al., 2012).

Ethanol is known to have a local effect on the stomach. The longer the ethanol is consumed, the more stomach cells will be damaged. The damage of the gastric mucosal barrier due to alcohol can cause acute and chronic gastritis. Excessive alcohol consumption can also cause superficial mucosal epithelial detachment (erosion). The severe form of erosion is a crucial cause of acute gastrointestinal bleeding (Goodman, 2008; Pan et al., 2008).

Medicinal plants that can be used in treating peptic ulcers are Lobak Putih or White Radish (Raphanus sativus) and Bengkuang or Jicama (Pachyrhizus erosus). Raphanus sativus contains flavonoid compounds, such as kaempferol, glycosides, peroxidase, and antioxidants (Beevi et al., 2012). Pachyrhizus erosus is included in the Fabaceae family, which is widely reported to contain phytoestrogens and may also contain flavonoids. Pachyrhizus erosus is presumed to have a potential source of antioxidants (Lukitaningsih, 2014). Furthermore, flavonoids have anti-ulcer and antiinflammatory effects through several mechanisms in their substances, namely inhibiting $\mathrm{K}^{+} / \mathrm{H}^{+}$ ATPase, decreasing $\mathrm{HCl}$ secretion, increasing PGE2 and COX-1 synthesis, and inhibiting the growth of Helicobacter pylori and antioxidants (Narayana et al., 2001). The ulcer research model shows that flavonoids can protect the gastric mucosa from damage. In addition, quercetin has an anti-secretory mechanism of action. Garcino, rutin, and quercetin compounds have antioxidant properties with mechanisms such as the inhibition of free radicals, transition of metal ions chelatin, inhibition of oxidizing enzymes, and reduction of lipid peroxidation (De Lira Mota et al., 2009).

Based on previous studies, Pachyrhizus erosus tuber juices are proven to reduce the number of ulcers formed due to ethanol's exposure. Gastric repair is indicated by a histopathological picture of the stomach, which shows a significant improvement in the distribution of Pachyrhizus erosus juice (Pertiwi and Saputra, 2019).

Therefore, this study conducted a test on the gastroprotective effect of Raphanus sativus and Pachyrhizus erosus juices on the stomach of ethanol-induced rats. Raphanus sativus and Pachyrhizus erosus contain flavonoid compounds that have an important role in the gastroprotective activity. The combination of Raphanus sativus and Pachyrhizus erosus is expected to provide significant gastric repair results compare to the use of only one juice.

\section{MATERIALS AND METHOD}

Materials

The materials used in this study were white radish, feed, sucralfate, $0.9 \% \mathrm{NaCl}, 96 \%$ ethanol, aquadest, and hematoxylin and eosin as coloring substances.

\section{Preparation sample}

The preparation was conducted by preparing fresh Raphanus sativus and Pachyrhizus erosus. The skin of the two ingredients was removed, then washed using running water to remove the dirt. Raphanus sativus and Pachyrhizus erosus that had been cleaned were mashed using a grater, and the grated results were then squeezed and filtered. Assembling the test preparation was carried out every day before the treatment.

\section{Experimental animals}

The experimental animals used were male mice. The mice used in this research were Swiss Webster mice with an average weight of around 20 grams. Furthermore, this research has been 
approved by the committee of Ethical Health Research Ethics, Faculty of Medicine and Health Sciences at the University of Bengkulu, and has been registered with the number 215/UN30.14.9/LT/2020. A total of 40 mice were divided into 8 groups. For 12 days, Group I (normal group) was only given food and drink, Group II (negative control group) was given food and drink, and Group III (positive control group) was given sucralfate at a dose of $130 \mathrm{mg} / \mathrm{kgBW}$. Meanwhile, Groups IV, V, and VI were given a combination of Raphanus sativus and Pachyrhizus erosus at a dose of 100, 300, and $600 \mathrm{mg} / \mathrm{kgBW}$. Group VI was given Raphanus sativus at a dose of $300 \mathrm{mg} / \mathrm{kgBW}$, and group VIII was given Pachyrhizus erosus at a dose of $300 \mathrm{mg} / \mathrm{kgBW}$. The treatment was carried out for 12 days by giving each dose orally. After one hour of treatment on the 12th day, $96 \%$ ethanol induction was given orally at a dose of $20 \mathrm{~mL} / \mathrm{kgBW}$, except for group I. Following the giving of ethanol induction, the animals were treated to be in a fasting condition. Animal dissection was performed after 24 hours of ethanol induction.

\section{Macroscopic observation of gastric ulcers}

To see the number and size of the lesions/ulcers formed, the gastric was isolated after the surgery. The observation was carried out by opening the gastric of the mice, which was then deeply observed from 5 points of view. The gastric was dissected on the largest curve (major curvature) and cleaned with $0.9 \% \mathrm{NaCl}$. Then, the gastric was spread on a flat surface to observe the ulcers formed (Gusdinar et al., 2009). The scores, according to Szabo et al., (1985), are presented in Table 1.

Table 1. Modified scoring of ulcer severity by Szabo et al (1985)

\begin{tabular}{llc}
\hline Gastric Cross Section & & Score \\
\hline Normal & & 0 \\
Hyperemia & Petechiae & 1 \\
Hemorrhage & Ecchymoses & 2 \\
& Purpura & 3 \\
Erosion & & 4 \\
\hline
\end{tabular}

Description: Hyperemia is a condition of dilated blood vessels with an excessive filling of blood granules. Erosion is the release of superficial mucosal epithelium. Hemorrhage (bleeding) is blood droplets leaving the blood vessels and scattered between the tissues. Petechiae are bleeding spots with the size of $0.1-0.2 \mathrm{~cm}$. Ecchymoses are bleeding spots with the size of $0.2-3.0 \mathrm{~cm}$. Purpura is a bleeding spot with the size of $>3 \mathrm{~cm}$ (Szabo et al., 1985)

The ulcer index (IU) is calculated based on the comparison between the total score and the number of animals in each group. The mean total score of each group's treatment was stated as an ulcer index or gastric ulcer index, which was then compared with the negative control group. The protective ability or protection ratio of the material towards the ulcer was calculated using the formula 1 (Saptarini and Suryasaputra, 2011).

$$
\% \text { Protection Ratio }=100 \%-\frac{\text { IU tested group }}{\text { IU Ulcer control }} \times 100 \%
$$

\section{Histopathological examination}

The gastric was placed in gauze, dehydrated, and soaked in a graded volume of ethanol solution, with the percentages of $70 \%, 80 \%, 90 \%, 100 \%, 100 \%$, and $100 \%$, respectively, for 60 minutes at room temperature. The next process was clearing the gastric using xylol at room temperature for 15 minutes; this process was repeated three times. After the clearing process, the infiltration process was conducted 
with liquid paraffin for 3 shifting times, in which each shifting was carried out for 60 minutes in a $60^{\circ} \mathrm{C}$ degree incubator. Subsequently, the gastric was immersed in liquid paraffin and cooled down at room temperature until it turned into a paraffin block.

Furthermore, the process of embedding and cutting was carried out using a horizontal microtome with a thickness of $3 \mu$. Toluidine blue painting was carried out using the following procedure: paraffin was removed using xylol, then put in $100 \%, 95 \%$, and $70 \%$ ethanol, respectively, for 5 minutes, and continued with putting it in distilled water. Toluidine blue painting was conducted for 40-60 minutes in a $60^{\circ} \mathrm{C}$ oven, which was then put in $70 \%, 95 \%$, and $100 \%$ ethanol. After the Canada balsam was added to it, it was covered with a glass deck. Two incisions were taken from each of the experimental animals, in which each incision was observed with a microscope from 5 points of view.

\section{Data Analysis}

The percentage of the protection was analyzed using SPSS. The analysis for the histopathological image of the gastric was conducted by observing it under a microscope. Gastric slice preparation analysis is carried out by observing the specific changes that occur in the gastric (Maslachah et al., 2008).

\section{RESULT AND DISCUSSION}

Raphanus sativus contain flavonoid compounds, such as kaempferol, glycosides, peroxidase, and antioxidants (Beevi et al., 2012). Pachyrhizus erosus to the Fabaceae family that is widely known to contain phytoestrogens and may contain flavonoids. Moreover, Pachyrhizus erosus is thought to have a potential source of antioxidants (Lukitaningsih, 2014). Flavonoids have anti-ulcer and antiinflammatory effects through several mechanisms of the substances they contain, namely through the inhibition of $\mathrm{K}+/ \mathrm{H}+$ ATPase, decrease in $\mathrm{HCl}$ secretion, increase in PGE2 and COX-1 synthesis, and inhibition of Helicobacter pylori growth and antioxidants (Narayana et al., 2001). The qualitative test of Raphanus sativus and Pachyrhizus erosus can be seen in Table 2.

Table 2. Qualitative test of Raphanus sativus and Pachyrhizus erosus

\begin{tabular}{lcc}
\hline Phytochemical Test & Raphanus sativus & Pachyrhizus erosus \\
\hline Flavonoid & + & + \\
Tanin & - & + \\
Alkaloid & + & + \\
Saponin & + & + \\
\hline
\end{tabular}

The gastroprotective effect for the impact of giving Raphanus sativus and Pachyrhizus erosus tubers was observed by looking at the anatomy and histopathology of the mice's gastric. The results of the gastric anatomy of mice treated with Raphanus sativus and Pachyrhizus erosus on the mice's macroscopic gastric anatomy can be seen in Figure 1, and the gastric ulcer index of alcohol-induced mice treated with Raphanus sativus and Pachyrhizus erosus can be seen in Table 3. 


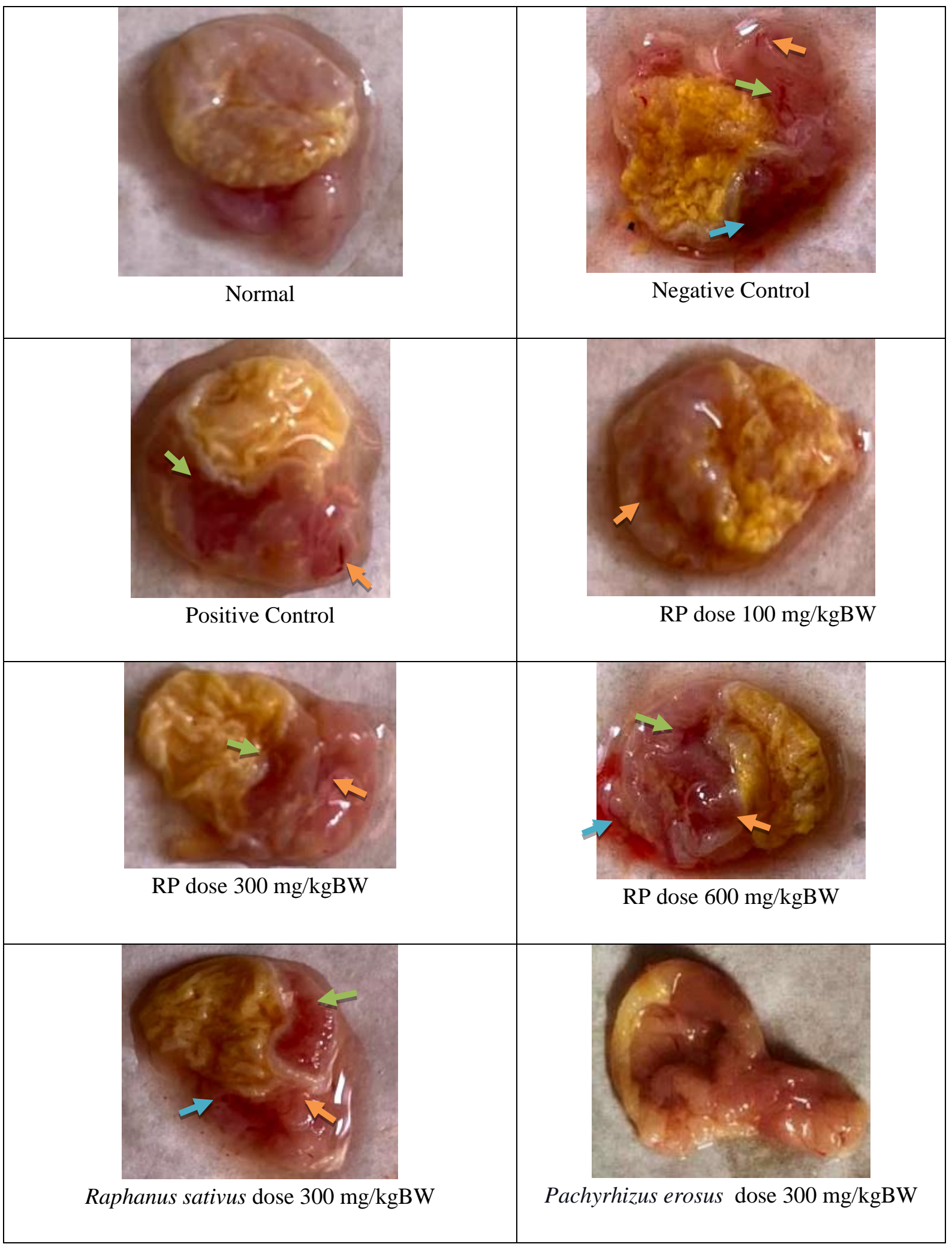

Figure 1. Macroscopic overview of mice's gastric after Raphanus sativus and Pachyrhizus erosus Tubers were given (RP: Raphanus sativus and Pachyrhizus erosus; $\Rightarrow$ : hemorrhage ecchymoses; $\rightarrow$ : hyperemia; and $\rightarrow$ : hemorrhage Purpura) 
Table 3. The gastric ulcer index of alcohol-induced mice treated with Raphanus sativus and Pachyrhizus erosus juices

\begin{tabular}{lcc}
\hline Groups & $\begin{array}{c}\text { Dose } \\
(\mathbf{m g} / \mathbf{k g B W})\end{array}$ & Mean \pm SD \\
\hline Normal & - & 0 \\
Negative Control & - & $4.00 \pm 0.82^{\mathrm{a}}$ \\
Positive Control (Sucralfate) & 130 & $2.00 \pm 0.81^{\mathrm{a}, \mathrm{b}}$ \\
Raphanus sativus + Pachyrhizus erosus juice & 100 & $1.00 \pm 0.41^{\mathrm{b}}$ \\
Raphanus sativus + Pachyrhizus erosus juice & 300 & $1.33 \pm 0.47^{\mathrm{b}}$ \\
Raphanus sativus + Pachyrhizus erosus juice & 600 & $2.33 \pm 0.47^{\mathrm{a}, \mathrm{b}}$ \\
Raphanus sativus Juice & 300 & $2.67 \pm 0.24^{\mathrm{a}, \mathrm{b}}$ \\
Pachyrhizus erosus juice & 300 & $0^{\mathrm{b}}$ \\
\hline
\end{tabular}

${ }^{\mathrm{a}} \mathrm{sig}<0.05$ there is a significant difference with the normal group.

${ }^{\mathrm{b}}$ sig $<0.05$ there is a significant difference between treatments.

SD: Standard Deviation

After the gastric ulcer index value was obtained, the value of the protection ratio was calculated. The results of the protection ratio can be seen in Table 4 .

Table 4. The protection ratio of alcohol-induced mice treated with Raphanus sativus and Pachyrhizus erosus juice

\begin{tabular}{lcc}
\hline Groups & $\begin{array}{c}\text { Dose } \\
(\mathbf{m g} / \mathbf{k g B W})\end{array}$ & $\begin{array}{c}\text { Protection Ratio } \\
(\mathbf{\%}) \pm \text { SD }\end{array}$ \\
\hline Normal & - & $100 \pm 0$ \\
Positive Control (Sucralfate) & 130 & $50.00 \pm 20.41^{\mathrm{a}, \mathrm{b}}$ \\
Raphanus sativus + Pachyrhizus erosus juice & 100 & $75.00 \pm 10.21^{\mathrm{b}}$ \\
Raphanus sativus + Pachyrhizus erosus juice & 300 & $66.67 \pm 11.79^{\mathrm{b}}$ \\
Raphanus sativus + Pachyrhizus erosus juice & 600 & $41.67 \pm 11.79^{\mathrm{a}, \mathrm{b}}$ \\
Raphanus sativus Juice & 300 & $33.33 \pm 5.89^{\mathrm{a}, \mathrm{b}}$ \\
Pachyrhizus erosus juice & 300 & $100 \pm 0^{\mathrm{b}}$ \\
\hline
\end{tabular}

${ }^{\mathrm{a}}$ sig $<0,05$ there is a significant difference with the normal group.

${ }^{b}$ sig $<0,05$ there is a significant difference between treatments

SD: Standard Deviation

The results show that the largest protection ratio was produced by giving only a single dose of Pachyrhizus erosus juice. According to previous studies, Pachyrhizus erosus tuber juices are proven to reduce the number of ulcers caused by ethanol's exposure. Gastric repair is indicated by a histopathological picture of the stomach, which shows a significant improvement in the distribution of Pachyrhizus erosus juice (Pertiwi and Saputra, 2019). Another study showed that there was a decrease in gastric lesions with treatment using radish Raphanus sativus on experimental gastric ulcer models at a dose of $20 \mathrm{~mL} / \mathrm{kgBW}$ (Alqasoumi et al., 2008). Treatment of extracts of Raphanus sativus leaf is reported to have gastroprotective activity with a significant decrease in ulcer index, free acidity, and total acidity (Devaraj et al., 2011).

Gastric histopathology observation of mice was also carried out to support the research results. In addition, histopathological observations also aim to see a picture of gastric tissue from the damage caused by gastric ulcer-inducing compounds and to see gastric tissue repair after giving Raphanus sativus and Pachyrhizus erosus juices. Following are the histological preparations of the mice's gastric, which will be analyzed after observation using a microscope. The results of gastric histopathology observations of mice can be seen in Figure 2. 


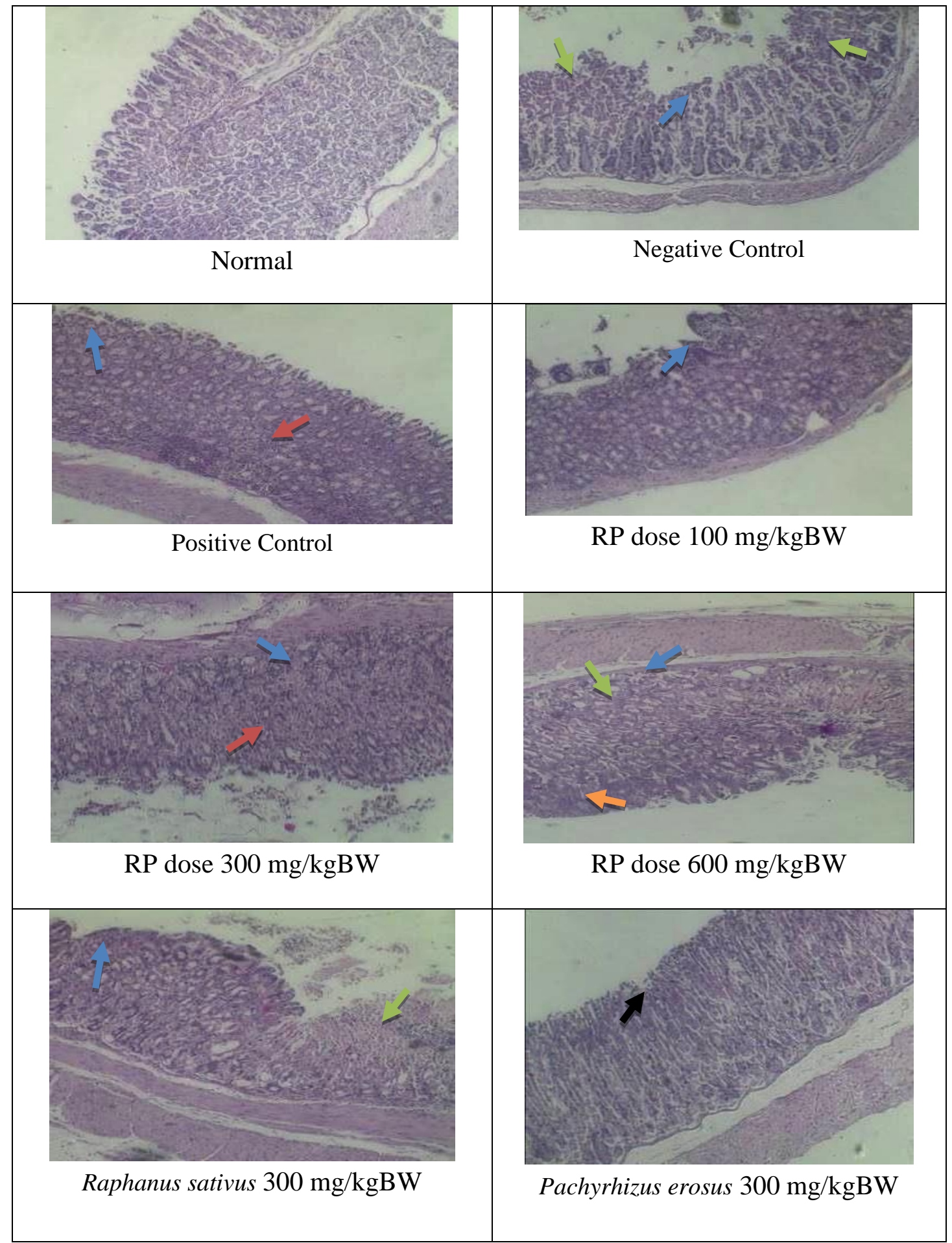

Figure 2. Histological preparation of mice's gastric after Raphanus sativus and Pachyrhizus erosus uber Juices were given (RP: Raphanus sativus and Pachyrhizus erosus; $>$ : ulcer; : lesions on the mucosa; $\rightarrow$ : bleeding; $\rightarrow$ : hemorrhage; $\rightarrow$ : gastric cell repair and no ulcer) 
Based on the mice's gastric anatomy observation, there were no characteristics that indicated gastric ulcers, such as hyperemia, hemorrhage petechiae, hemorrhage ecchymoses, hemorrhage purpura, or erosion (loss of gastric wall tissue). There were no bleeding and injuries seen from the macroscopic anatomy in the gastric of mice after being treated with Pachyrhizus erosus at a dose of $300 \mathrm{mg} / \mathrm{kgBB}$. Pachyrhizus erosus tubers are identified to contain adenine, choline, saponins and flavonoid compounds (Catteau et al., 2013).

Flavonoids can become cytoprotective agents with various mechanisms, namely stabilizing membranes and influencing several intermediate metabolic processes, peroxiding lipid by increasing the activity of the Superoxide Dismutase (SOD) enzyme, and increasing the prostaglandin content of the gastric mucosa by stimulating cyclooxygenase (COX-1) and having anti-inflammatory activity. In addition, Helicobacter pylori can prevent recurrence (Islamiah and Sukohar, 2017). According to Robiyanto and Marsela, (2018), alkaloids can increase the secretion of alkali and mucus, reduce gastric acid secretion, and help cure and prevent gastric ulcers against irritant agents/factors by improving blood flow to the gastric mucosa. Alkaloids are responsible for proton pump of $\mathrm{H}+$ inhibition, K+ ATPase and can increase mucus secretion (Do Nascimento et al., 2015). Antimicrobial effects in tannins can help the defense against Helicobacter pylori to prevent gastric ulcer recurrence (Indraswari, 2011). Saponins also have an inhibitory effect on the formation of lesions on the gastric mucosa (Islamiah and Sukohar, 2017).

From the results of histopathological observations, it can be seen that there is an improvement in the gastric tissue of mice when the Pachyrhizus erosus juice was given. The histopathological picture of the gastric shows a picture that is almost the same as the histopathology of the normal gastric.

\section{CONCLUSION}

The Pachyrhizus erosus juice can prevent gastric damages in mice caused by ethanol induction. However, in this study, Pachyrhizus erosus is proven to be better at preventing gastric damage compared to Raphanus sativus juice and the combination of Raphanus sativus and Pachyrhizus erosus juices.

\section{ACKNOWLEDGEMENT}

The deepest gratitude is addressed to the Institute for Research and Community Service at the University of Bengkulu for the funding of the research through the university development research scheme with contract number 2038/UN30.15/PG/2020.

\section{REFERENCES}

Alqasoumi, S., Al-Yahya, M., Al-Howiriny, T., \& Rafatullah, S. (2008). Gastroprotective effect of radish "Raphanus sativus" L. on experimental gastric ulcer models in rats. Farmacia, 56(2), 204-214

Beevi, S. S., Mangamoori, L. N., \& Gowda, B. B. (2012). Polyphenolics profile and antioxidant properties of Raphanus sativus L. Natural Product Research, 26(6), 557-563. https://doi.org/10.1080/14786419.2010.521884

Catteau, L., Lautié, E., Koné, O., Coppée, M., Hell, K., Pomalegni, C. B., \& Quetin-Leclercq, J. (2013). Degradation of rotenone in yam bean seeds (Pachyrhizus sp.) through food processing. Journal of Agricultural and Food Chemistry, 61(46), 11173-11179. https://doi.org/10.1021/jf402584k

De Lira Mota, K. S., Dias, G. E. N., Pinto, M. E. F., Luiz-Ferreira, Â., Souza-Brito, A. R. M., HirumaLima, C. A., Barbosa-Filho, J. M., \& Batista, L. M. (2009). Flavonoids with gastroprotective activity. Molecules, 14(3), 979-1012. https://doi.org/10.3390/molecules14030979

Devaraj, V. C., Gopala Krishna, B., Viswanatha, G. L., Satya Prasad, V., \& Vinay Babu, S. N. (2011). Protective effect of leaves of Raphinus sativus Linn on experimentally induced gastric ulcers in rats. Saudi Pharmaceutical Journal, 19(3), 171-176. https://doi.org/10.1016/j.jsps.2011.03.003

Dharmani, P., Kumar, K., Srivastava, S., \& Palit, G. (2012). Ulcer Healing Effect Of Anti-Ulcer 
Agents: A Comparative Study. The Internet Journal of Academic Physician Assistants, 3(2), 17. https://doi.org/10.5580/11e2

Do Nascimento, R. F., De Sales, I. R. P., De Oliveira Formiga, R., Barbosa-Filho, J. M., Sobral, M. V., Tavares, J. F., De Fátima Formiga Melo Diniz, M., \& Batista, L. M. (2015). Activity of alkaloids on peptic ulcer: What's new? Molecules, 20(1), 929-950. https://doi.org/10.3390/molecules20010929

Goodman, G. (2008). Manual Farmakologi dan Terapi. Penerbit buku kedokteran EGC

Gusdinar, T., Herowati, R., Kartasasmita, R. E., I, D., \& Adnyana, K. (2009). Sintesis kuersetin terklorinasi dan aktivitas perlindungan terhadap tukak lambung Synthesis and gastric ulcer protective activity of chlorinated quercetin. Majalah Farmasi Indonesia, 20(204), 163-169

Indraswari, R. (2011). Efek konsentrasi buah adas (Foeniculum vulgare mill.) topikal pada epitelisasi penyembuhan luka gingiva labial Tikus Sprague Dawley in vivo. Majalah Sultan Agung Unissula.

Islamiah, M. R., \& Sukohar, A. (2017). Efektivitas kandungan zat aktif daun cincau hijau ( Cyclea barbata Miers ) dalam melindungi mukosa lambung terhadap ketidakseimbangan faktor agresif dan faktor defensif lambung. Majority, 7(November), 41-48

Lukitaningsih, E. (2014). Bioactive compounds in bengkoang (Pachyrhizus erosus) AS antioxidant and tyrosinase inhibiting agents. Indonesian Journal of Pharmacy, 25(2), 68. https://doi.org/10.14499/indonesianjpharm25iss2pp68-75

Maslachah, L., Sugihartuti, R., \& Ankestri, H. (2008). The histopathology description of white rat ( Rattus norvegicus ) intestine that was given juice of noni ( Morinda citrifolia ) and high fatty diet. Media Veterinaria Medika, 1(3), 2008

Narayana, K. R., Reddy, M. S., Chaluvadi, M. R., \& Krishna, D. R. (2001). Bioflavonoids classification, pharmacological, biochemical effects and therapeutic potential. Indian Journal of Pharmacology, 33(1), 2-16

Pan, J. S., He, S. Z., Xu, H. Z., Zhan, X. J., Yang, X. N., Xiao, H. M., Shi, H. X., \& Ren, J. L. (2008). Oxidative stress disturbs energy metabolism of mitochondria in ethanol-induced gastric mucosa injury. World Journal of Gastroenterology, 14(38), 5857-5867. https://doi.org/10.3748/wjg.14.5857

Pertiwi, R., \& Saputra, H. M. (2019). Pengaruh perasan umbi Bengkuang (Pachyrhizus erosus L.) terhadap gambaran histopatologi lambung Mencit (Mus musculus L.) dengan model tukak lambung. Jurnal Farmasi Dan Ilmu Kefarmasian Indonesia, 5(2), 56. https://doi.org/10.20473/jfiki.v5i22018.56-61

Robiyanto, R., \& Marsela, M. (2018). Potensi antiulser seduhan serbuk buah mengkudu dan kulit daun lidah buaya terhadap gambaran makroskopik lambung. Edukasi: Jurnal Pendidikan, 16(2), 182. https://doi.org/10.31571/edukasi.v16i2.946

Saptarini, M, N., \& Suryasaputra, D. (2011). Analisis Rasio Proteksi Antiulser Sari Buah Pepino (Solanum muricatum Aiton) menggunakan Mencit sebagai model hewan coba. Majalah Obat Tradisional, 16(2), 75-80

Szabo, S., Trier, J. S., Brown, A., Schnoor, J., Homan, H. D., \& Bradford, J. C. (1985). A quantitative method for assessing the extent of experimental gastric erosions and ulcers. Journal of Pharmacological Methods, 13(1), 59-66. https://doi.org/10.1016/0160-5402(85)90068-3 